\title{
Refining selection criteria for cytoreductive surgery and hipec
}

Citation for published version (APA):

Simkens, G. A. A. M. (2017). Refining selection criteria for cytoreductive surgery and hipec: in patients with peritoneal metastases of colorectal origin. [Doctoral Thesis, Maastricht University]. Maastricht University. https://doi.org/10.26481/dis.20170113gs

Document status and date:

Published: 01/01/2017

DOI:

10.26481/dis.20170113gs

Document Version:

Publisher's PDF, also known as Version of record

\section{Please check the document version of this publication:}

- A submitted manuscript is the version of the article upon submission and before peer-review. There can be important differences between the submitted version and the official published version of record.

People interested in the research are advised to contact the author for the final version of the publication, or visit the DOI to the publisher's website.

- The final author version and the galley proof are versions of the publication after peer review.

- The final published version features the final layout of the paper including the volume, issue and page numbers.

Link to publication

\footnotetext{
General rights rights.

- You may freely distribute the URL identifying the publication in the public portal. please follow below link for the End User Agreement:

www.umlib.nl/taverne-license

Take down policy

If you believe that this document breaches copyright please contact us at:

repository@maastrichtuniversity.nl

providing details and we will investigate your claim.
}

Copyright and moral rights for the publications made accessible in the public portal are retained by the authors and/or other copyright owners and it is a condition of accessing publications that users recognise and abide by the legal requirements associated with these

- Users may download and print one copy of any publication from the public portal for the purpose of private study or research.

- You may not further distribute the material or use it for any profit-making activity or commercial gain

If the publication is distributed under the terms of Article $25 \mathrm{fa}$ of the Dutch Copyright Act, indicated by the "Taverne" license above, 

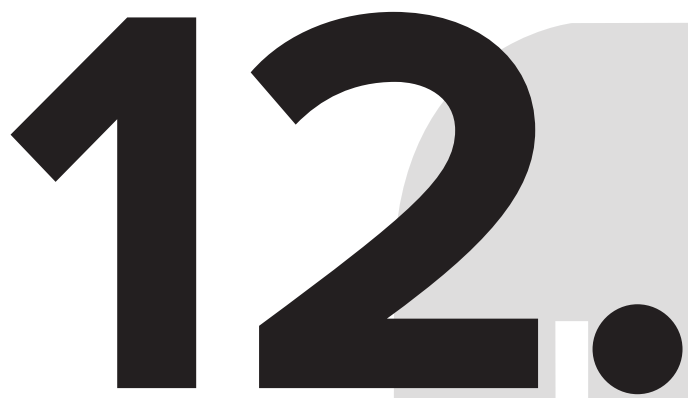

Nederlandse Samenvatting

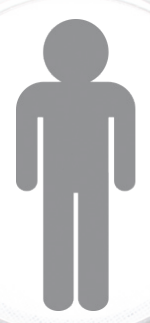


Dikkedarm/endeldarmkanker, ook bekend als het colorectaal carcinoom, is de eenna-meest voorkomende vorm van kanker. Met zo'n 12\% heeft deze vorm van kanker een belangrijk aandeel in het aantal kanker-gerelateerde doden in Nederland. Daarbij is de belangrijkste reden van overlijden het uitzaaien van de kanker naar andere plekken in het lichaam, ook wel metastasering genoemd. Deze thesis gaat over de behandeling van patiënten met peritoneaal metastasen (PM) van het colorectaal carcinoom. Dit zijn uitzaaiingen van het colorectaal carcinoom naar het buikvlies, dat de binnenkant van de buikholte bekleed. De behandeling met cytoreductieve chirurgie (CRS) en hypertherme intraperitoneale chemotherapie (HIPEC) staat hierbij centraal. Tijdens deze intensieve chirurgische behandeling wordt alle zichtbare tumor uit de buikholte verwijderd, waarna de buik gespoeld wordt met HIPEC om de achtergebleven tumorcellen te behandelen. Daar waar dit voorheen niet mogelijk was, kan met deze behandeling langdurige overleving worden behaald bij een deel van de patiënten met PM van colorectale origine. Dit proefschrift richt zich op het verfijnen van de patiëntselectie voor deze chirurgische behandeling. Hierbij is voornamelijk gebruik gemaakt van data van patiënten die deze operatie door de jaren heen hebben ondergaan in het Catharina Ziekenhuis te Eindhoven. Hieronder volgt een samenvatting van de belangrijkste resultaten en conclusies uit dit proefschrift.

\section{Deel I: Korte termijn uitkomsten na CRS \& HIPEC}

Deel Ivan dit proefschrift is voornamelijkgerichtop hetverfijnen van de patiëntselectie op basis van de korte termijn uitkomsten na CRS \& HIPEC.

Behandeling-gerelateerde complicaties en sterfte na CRS \& HIPEC zijn vergelijkbaar met andere vormen van uitgebreide gastro-intestinale chirurgie. Desondanks blijft de korte termijn uitkomst een belangrijk onderwerp van gesprek in de behandeling van patiënten met colorectale PM. Dit vraagt om betrouwbare uitkomstmaten voor behandeling-gerelateerde complicaties en sterfte. Daarom zijn in hoofdstuk 2 bij 245 patiënten de oorzaken van sterfte binnen één jaar na CRS \& HIPEC onderzocht. In dit cohort was de 1-jaars sterfte na CRS \& HIPEC 14\%. Met 4.9\% was de 1-jaars behandeling-gerelateerde sterfte veel hoger dan werd beschreven met de conventionele sterfte binnen 30 dagen (1.6\%). Dit geeft aan dat CRS \& HIPEC ook na 30 dagen postoperatief tot sterfte kan lijden. Ondanks deze bevinding was vroeg recidiverende ziekte de belangrijkste oorzaak van overlijden binnen één jaar na CRS \& HIPEC. De uitgebreidheid van ziekte in de buikholte, uitgedrukt in de peritoneal cancer index $(\mathrm{PCl})$ score, was de belangrijkste factor geassocieerd met 
1-jaars sterfte. Deze resultaten laten zien dat conventionele uitkomstmaten na CRS \& HIPEC voorzichtig geïnterpreteerd dienen te worden. De verlengde impact van uitgebreide chirurgie zoals CRS \& HIPEC hoort dan ook te worden meegenomen wanneer men patiënten voorlicht over deze procedure en wanneer uitkomsten worden gerapporteerd. Idealiter zal dit leiden tot betrouwbaardere behandelinggerelateerde uitkomsten na CRS \& HIPEC.

Het terugkeren van kanker na behandeling met CRS \& HIPEC is geassocieerd met een verminderde overleving. Daarom zijn in hoofdstuk 3 risicofactoren voor recidief ziekte binnen één jaar na CRS \& HIPEC geïdentificeerd. In deze studie ontwikkelde 35\% van de 133 colorectale PM patiënten na CRS \& HIPEC een vroeg recidief. Hierbij was het optreden van ernstige complicaties na CRS \& HIPEC de belangrijkste risicofactor voor het ontwikkelen van een recidief binnen één jaar (2.3x hogere kans). In deze studie was zowel een vroeg recidief als het optreden van ernstige complicaties geassocieerd met een verminderde overleving. Deze resultaten onderstrepen het belang van het minimaliseren van complicaties na CRS \& HIPEC. Kortom, verbeterde patiëntselectie met als doel het voorkomen van complicaties lijdt mogelijk tot zowel betere korte- als lange termijnresultaten na CRS \& HIPEC.

Naast de impact van complicaties op de korte- en lange termijn, leidt een gecompliceerd beloop na CRS \& HIPEC mogelijk tot hogere ziekenhuiskosten. Hoofdstuk 4 laat zien dat de patiënten met ernstige complicaties (31\%) voor $55 \%$ van de ziekenhuiskosten na de CRS \& HIPEC procedure zorgden. Totale ziekenhuiskosten waren $€ 3.000$ hoger bij patiënten met milde complicaties en $€$ 10.000 hoger bij patiënten met ernstige complicaties. Intensive care kosten waren relatief hoog en bieden een mogelijke optie om kosten op te besparen. Secundair aan de patiënt-gerelateerde consequenties van complicaties, onderstrepen deze financiële resultaten het belang van het minimaliseren van het risico op complicaties. Zoals hierboven beschreven zijn ernstige complicaties na CRS \& HIPEC geassocieerd met verminderde lange termijnuitkomsten en verhoogde ziekenhuiskosten. Vandaar dat in hoofdstuk 5 bij 211 patiënten risicofactoren voor het optreden van ernstige complicaties na CRS \& HIPEC zijn onderzocht. Geïdentificeerde risicofactoren voor ernstige complicaties waren uitgebreide voorafgaande buikchirurgie (4.3x hogere kans), roken (4.0x hogere kans), een verminderde fysieke status (2.9x hogere kans) en uitgebreide cytoreductieve chirurgie tijdens CRS \& HIPEC (1.2x hogere kans per extra resectie). Patiënten met meerdere risicofactoren hadden een grotere kans op ernstige complicaties, een re-operatie of een heropname. De beslissing om patiënten met meerdere risicofactoren met CRS \& HIPEC te behandelen zou 
daarom weloverwogen dienen te worden genomen. Ondanks dat CRS \& HIPEC voor deze patiënten vaak de enige mogelijkheid op langdurige overleving is, moet deze procedure niet ten koste van alles worden uitgevoerd. Het preoperatieve voorspellingsmodel kan bij deze complexe beslissing een extra hulpmiddel zijn.

\section{Deel II: Lange termijn uitkomsten na CRS \& HIPEC}

Het behalen van lange termijnoverleving is het primaire doel van de CRS \& HIPEC behandeling bij patiënten met colorectale PM. Daarom is het tweede gedeelte van dit proefschrift gericht op het bepalen van de invloed van een aantal factoren op de overleving van deze patiënten. Deze resultaten leiden tot meer inzicht in welke patiënten het meeste baat hebben bij een behandeling met CRS \& HIPEC.

Idealiter worden colorectale PM patiënten geselecteerd voor CRS \& HIPEC op basis van een combinatie van een aantal relevante prognostische factoren. Daarom is in hoofdstuk 6 de voorspellende waarde van de reeds bestaande 'Peritoneal Surface Disease Severity Score' (PSDSS) getoetst, welke suboptimaal bleek. Daarom is een nieuwe score ontwikkeld om de overleving na CRS \& HIPEC te voorspellen: de 'Colorectal Peritoneal Metastases Prognostic Surgical Score' (COMPASS). Deze precytoreductie score is gebaseerd op vier relevante prognostische factoren: Leeftijd, de $\mathrm{PCl}$ score, de locoregionale lymfeklier status en zegelring cell carcinoom histologie. De COMPASS voorspelde de overleving adequaat bij 200 patiënten met colorectale PM na CRS \& HIPEC. Deze score kan daarom gebruikt worden als hulpmiddel bij de beslissing om cytoreductie en HIPEC uit te voeren. Bovendien kan de COMPASS waardevol zijn voor patiënten en chirurgen in de vervolgperiode na CRS \& HIPEC. De mobiele app maakt de COMPASS bovendien gebruiksvriendelijk en toegankelijk voor clinici betrokken bij de behandeling van patiënten met colorectale PM.

Aangezien het optimale tijdstip voor behandeling met systemische chemotherapie in aanvulling op CRS \& HIPEC onduidelijk is, werd dit in hoofdstuk 7 onderzocht bij patiënten met synchrone colorectale PM. In deze studie werden 24 patiënten behandeld met preoperatieve chemotherapie en vergeleken met 64 patiënten die volgens standaardprotocol zijn behandeld met aanvullende chemotherapie na de operatie. Met 89\% 3-jaars overleving was de lange termijn uitkomst van patiënten die behandeld zijn volgens de preoperatieve strategie beter dan de 51\% 3-jaars overleving van patiënten die behandeld zijn volgens de aanvullende strategie. Verder was preoperatieve chemotherapie niet geassocieerd met meer complicaties na CRS \& HIPEC. Deze overlevingswinst is veelbelovend, zeker aangezien uitgebreide tumorgroei de belangrijkste reden voor het kiezen van de preoperatieve strategie 
was. Desalniettemin is deze studie gelimiteerd omdat patiënten met progressie van ziekte onder preoperatieve chemotherapie niet meer in aanmerking kwamen voor CRS \& HIPEC en dus ook geen onderdeel waren van de onderzochte populatie. Om deze veelbelovende resultaten te kunnen toetsen is er in de toekomst meer onderzoek zonder deze beperking nodig.

De resultaten van CRS \& HIPEC bij patiënten met PM van het rectum (endeldarm) zijn onduidelijk. Daarom zijn in hoofdstuk 8 de haalbaarheid en de resultaten van CRS \& HIPEC bij 29 patiënten met rectale PM vergeleken met de resultaten van 58 patiënten met PM van het colon (dikkedarm). Vergeleken met colon PM patiënten hadden rectum PM patiënten een vergelijkbare overleving (de 1, 2, en 5-jaars overleving waren $82 \%, 54 \%$, en $32 \%$ in de rectum groep en $83 \%$, 61\%, en 24\% in de colon groep). De uitgebreidheid van cytoreductieve chirurgie was vergelijkbaar in beide groepen en ernstige complicaties traden op bij 28\% van de rectum PM patiënten en 35\% van de colon PM patiënten. Deze resultaten laten zien dat PM van het rectum niet per definitie een contra-indicatie is voor CRS \& HIPEC. Men moet echter wel in gedachte houden dat deze resultaten niet gelden voor elke patiënt met rectale $\mathrm{PM}$ en dat een individuele aanpak gewenst is.

In hoofdstuk 9 werd bij 5516 patiënten met synchrone colorectale PM de impact van histologisch subtype en de aanwezigheid van systemische metastasen op de behandeling en overleving onderzocht. Vergeleken met 6\% van de patiënten met een adenocarcinoom (AC) werden patiënten met een mucineus adenocarcinoom (MC) en een zegelringcel carcinoom (ZRCC) vaker behandeld met CRS \& HIPEC (13\% en $11 \%$, respectievelijk). De belangrijkste reden hiervoor was het hoge percentage systemische metastasen bij AC patiënten. In de loop van de tijd is het percentage $A C$ en MC patiënten dat is behandeld met CRS \& HIPEC toegenomen, terwijl het percentage ZRCC patiënten lijkt te zijn gestabiliseerd. Alhoewel de absolute overlevingswinst na het ondergaan van CRS \& HIPEC verschilt, is de relatieve overlevingswinst vergelijkbaar tussen alle histologische typen. Behandeling met systemische therapie resulteerde bij alle histologische typen tot een betere overleving. Deze resultaten onderstrepen zowel het belang als het effect van tumorhistologie op de behandelstrategie en overleving van colorectale PM patiënten.

In dit proefschrift zijn verschillende aspecten rondom de CRS \& HIPEC behandeling van colorectale PM patiënten onderzocht. De gevonden resultaten en conclusies leiden tot meer inzicht in welke factoren invloed hebben op de uitkomsten na deze uitgebreide vorm van chirurgie. Dit draagt in de toekomst hopelijk bij aan een efficiëntere en meer patiëntgerichte behandeling van patiënten met colorectale PM. 
i
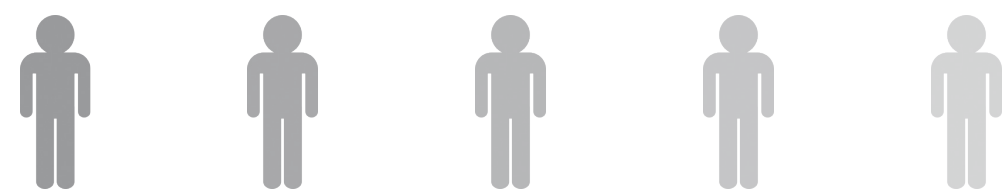

i
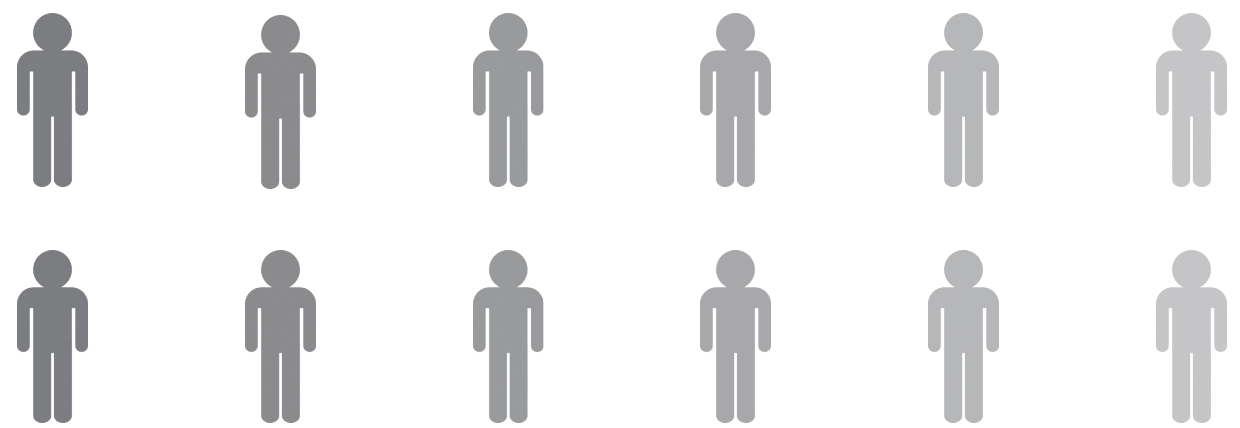

in
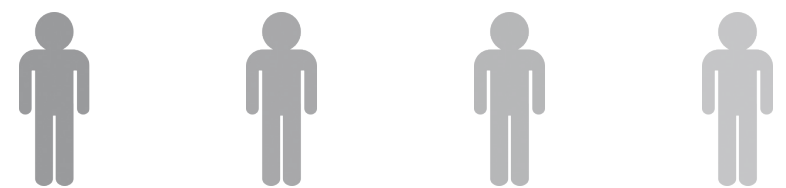